Original Article

\title{
Hancornia speciosa serum latex fraction: a non-allergenic biomaterial
}

\author{
Fração soro do látex de Hancornia speciosa: um biomaterial não alergênico
}

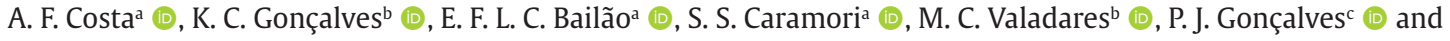 \\ L. M. Almeida ${ }^{\text {** }}$ (D) \\ aUniversidade Estadual de Goiás - UEG, Laboratório de Biotecnologia, Campus Henrique Santillo, Anápolis, GO, Brasil \\ bUniversidade Federal de Goiás - UFG, Faculdade de Farmácia, Laboratório de Pesquisa, Desenvolvimento \& Inovação de Bioprodutos, Goiânia, \\ GO, Brasil \\ 'Universidade Federal de Goiás - UFG, Instituto de Física, Goiânia, GO, Brasil
}

\begin{abstract}
Plant-derived products can assist in the healing process of dermal wounds. It has been demonstrated that Hancornia speciosa latex present angiogenic, osteogenic, anti-inflammatory, and antioxidant activities. Then, it could contribute to the wound healing process. However, natural products in contact with skin may cause dermatitis. The objective of this work was to evaluate the allergic and irritant potential of H. speciosa serum fraction latex using in vitro assays. The obtained results showed that the $H$. speciosa serum fraction latex has a slightly irritant potential and is not cytotoxic neither allergenic for human cells. Moreover, we identified a remarkable low amount of proteins in this material in comparison to Hevea brasiliensis latex. This result could explain the non-allergenic potential of $H$. speciosa serum fraction latex because proteins present in latex are the main responsible for allergy. This biomaterial could be used as a non-allergenic source for development of new medicines.
\end{abstract}

Keywords: allergic contact dermatitis, chronic wounds, irritant contact dermatitis, mangabeira, wound healing.

\begin{abstract}
Resumo
Produtos derivados de plantas podem auxiliar no processo de cicatrização de feridas cutâneas. Foi demonstrado que o látex de Hancornia speciosa apresenta atividades angiogênicas, osteogênicas, antiinflamatórias e antioxidantes. Então, este biomaterial pode contribuir para o processo de cicatrização de feridas. No entanto, produtos naturais em contato com a pele podem causar dermatites. $O$ objetivo deste trabalho foi avaliar o potencial alérgico e irritante do látex da fração soro de $H$. speciosa por meio de ensaios in vitro. Os resultados obtidos mostraram que o látex da fração do soro de $H$. speciosa possui um potencial pouco irritante e não é citotóxico nem alergênico para células humanas. Além disso, foi identificado uma notável baixa quantidade de proteínas neste material em comparação ao látex de Hevea brasiliensis. Esse resultado poderia explicar o potencial não alergênico do látex da fração soro de H. speciosa, pois as proteínas presentes no látex são as principais responsáveis pela alergia. Este biomaterial pode ser utilizado como fonte não alergênica para desenvolvimento de novos medicamentos.
\end{abstract}

Palavras-chave: dermatite alérgica de contato, feridas crônicas, dermatite de contato irritante, mangabeira, cicatrização de feridas.

\section{Introduction}

The healing of chronic wounds is considered a public health problem because of the protracted and intensive high-cost treatment, which could require prolonged hospitalizations, home care, complex treatments, and adjuvant therapies (Cavassan et al., 2019). In addition, chronic wounds on lower extremities reduce the mobility and affect the life quality (Santos et al., 2017) and could develop psychological problems due to longer treatments. For decades, researchers are looking for products or strategies to accelerate the wound healing process and topical treatments using natural products can be useful in

this process. Topical wound-care therapies using natural products has the advantage of low cost when compared to conventional wound-care products. An example of a natural product with wound healing properties is the natural rubber latex (NRL). The NRL is the main compound of the commercial products called Biocure ${ }^{\circledR}$ and Regederm ${ }^{\circledR}$, which are medicines able to stimulate angiogenesis and granulation tissue growth, accelerating the wound healing process (Biocure Pharma Biotechnology, 2021). The obtained results with those products showed the excellent potential of NRL to produce tissues replacement and regeneration

*e-mail: almeidalm@hotmail.com; luciane.almeida@ueg.br

Received: April 14, 2021 - Accepted: July 1, 2021 
(Floriano et al., 2014, 2016; Moura et al., 2014; Araújo et al., 2012). However, allergy to NRL products has been reported (Kelly and Sussman, 2017). Up to now, there is no specific treatment for NRL allergy, except the total avoidance of NRL-based products. Contact dermatitis, which could be caused by NRL, includes irritant contact dermatitis and allergic contact dermatitis. An alternative for NRL in biomedical applications could be the identification of other latex with similar biological activities with less allergenic substances. The latex of Hancornia speciosa, popularly known as mangabeira, presented high angiogenic (Almeida et al., 2014) and osteogenic potentials, as well as anti-inflammatory (Marinho et al., 2011), and antioxidant (D'Abadia et al., 2020) activities and can be used for controlled drug delivery (Almeida et al., 2019; Bonete et al., 2020). In addition, no cytogenotoxicity effects of $H$. speciosa latex were observed (Almeida et al., 2014; Ribeiro et al., 2016). All those properties may suggest that $H$. speciosa latex present potential for the development of medicines. Therefore, we investigated the sensitizer potential of $H$. speciosa latex looking for a non-allergenic biomaterial to be used in treatment of chronic wounds.

\section{Material and Methods}

\subsection{Latex collection}

The latex of $H$. speciosa was collected from Universidade Estadual de Goiás tree collection, in the city of Ipameri, (State of Goiás - Brazil). A voucher specimen was deposited at the Herbarium of Universidade Estadual de Goiás, Anápolis, Goiás, Brazil, under code number 4875. The procedure of latex collection is described by Arruda et al. (2016). In addition, we also used as positive control, the Hevea brasilensis serum latex for total protein determination. The latex was collected according producer's collection method in a commercial farm (Ouro Verde Farm, 151'38.0”S, 490'09.6”W).

\subsection{Hancornia speciosa latex fractionation}

H. speciosa latex was centrifuged at $4{ }^{\circ} \mathrm{C}$ for $1 \mathrm{~h}$ at 22.000 g. After centrifugation, the rubber was carefully separated, and a new centrifugation was performed to remove any phase contaminants. After latex centrifugation is possible to obtain two different fractions: 1) the top white zone with the rubber particles; and 2) the serum layer containing large variety of proteins and luteoids compounds. According to previous study, the serum layer fraction stimulates the angiogenesis and extracellular matrix remodeling processes (D'Abadia et al., 2020) and was chosen to perform this study. The same fractionation method was employed in Hevea brasilensis latex to obtain the sample control for the total protein quantification analysis.

\subsection{Irritation potential evaluated by HET-CAM test method}

This study was approved by the Ethics Committee on the use of animals at the Universidade Estadual de Goiás (Protocol number 07/2018). The method used in this manuscript was described by Luepke (1985). Briefly, each substance was tested on four fertilized eggs, in experimental triplicate performed on different days. The eggs were incubated for 10 days prior to expose the CAM to $300 \mu \mathrm{L}$ of the following testing solutions: 1 ) H. speciosa latex serum fraction, 2 ) $0.9 \%$ sodium chloride (negative control), and 3) $0.1 \%$ sodium hydroxide (positive control). After CAM exposition the irritation produced was evaluated according to Luepke scale, which give time-dependent numerical value for the following phenomena that indicate irritation: hyperemia, hemorrhage, and coagulation. The attributed value indicates the irritation potential of the tested substance on a scale with a maximum value of 21 (Table 1). After obtaining the numerical value using Luepke scale, the tested substance was classified according to Table 2 in not irritant, slightly irritant, moderately irritant or irritant.

\subsection{Total protein quantification}

For the Bradford method, a standard curve was first prepared using the albumin ( $1 \mathrm{mg} / \mathrm{mL} \mathrm{BSA}$ ) and its serial dilutions in $\mathrm{H}_{2} \mathrm{O}(0.5 \mathrm{mg} / \mathrm{mL} ; 0.25 \mathrm{mg} / \mathrm{mL}$ and $0.125 \mathrm{mg} / \mathrm{mL})$. H. speciosa serum latex samples were prepared using $2.37 \mathrm{~mL}$ of water, $30 \mu \mathrm{L}$ of serum fraction latex and $600 \mu \mathrm{L}$ of Bradford (Bradford, 1976). The mixture was incubated for $5 \mathrm{~min}$ in the dark and was measured at $595 \mathrm{~nm}$ (SpectraMax Paradigm). The same protocol was used for measuring the total protein in $H$. brasiliensis serum fraction latex.

\subsection{Myeloid U937 Skin Sensitization Test (U-SENS ${ }^{\text {TM }}$ )}

The skin sensitization potential of $H$. speciosa serum latex was evaluated by U-SENS ${ }^{\mathrm{TM}}$ method for quantification of changes in CD86 expression on the surface of U937 cells after incubation with the tested substance (OECD, 2016). The U937 cells (Rio de Janeiro Cell Bank, Brazil) were supplemented with $10 \%$ human serum, $2 \mathrm{mM}$ L-Glutamine and $1 \%$ Penicillin/Streptomycin, and remained in cell culture greenhouses (Thermo Scientific Revco $\mathrm{CO}_{2}$ cell incubator) at $37^{\circ} \mathrm{C}$, atmospheric $\mathrm{CO}_{2}$ at $5 \%$, and controlled humidity.

Table 1. Luepke scale for the appearance of the phenomena as function of the time.

\begin{tabular}{lccc}
\hline Phenomena & $\mathbf{T} \leq \mathbf{3 0 s}$ & $\mathbf{3 0 s}>\mathbf{T} \leq \mathbf{2} \mathbf{m i n}$ & $\mathbf{2 m i n}>\mathbf{T} \leq \mathbf{5 m i n}$ \\
\hline Hyperemia & 5 & 3 & 1 \\
Hemorrhage & 7 & 5 & 3 \\
Coagulation & 9 & 7 & 5 \\
\hline
\end{tabular}

Table 2. Classification of products according to the scores of the phenomena.

\begin{tabular}{cc}
\multicolumn{2}{c}{ Irritant potential } \\
\hline Het-CAM index & Classification \\
\hline $\mathrm{N} \leq 1$ & non-irritant \\
$1<\mathrm{N} \geq 5$ & slightly irritant \\
$5<\mathrm{N} \geq 9$ & moderately irritant \\
$9<\mathrm{N} \geq 21$ & severely irritant \\
\hline
\end{tabular}


First, the cytotoxicity of $H$. speciosa serum fraction latex was investigated to determine the latex concentration able to promote U937 cell viability $\geq 70 \%\left(\mathrm{CV}_{70}\right)$. Briefly, $100 \mu$ cells $\left(5 \times 10^{5}\right.$ cells $\left./ \mathrm{ml}\right)$ were plated in each well of a 96 well plate. After that, $H$. speciosa serum latex at 200,100 , 50,25 , and $12.5 \mu \mathrm{g} / \mathrm{ml}$, previously determined by Bradfold method, was dissolved in $100 \mu \mathrm{l}$ of RPMI1640 medium and the plates were incubated for $45 \mathrm{~h}$. Cells were then washed twice with ice-cold PBS and the cell viability was determined by propidium iodide (PI, $3 \mu \mathrm{g} / \mathrm{mL}$ ) staining.

The U-SENS ${ }^{\mathrm{TM}}$ assay was performed in biological quadruplicate and two independent runs (performed on a different day), according to de Ávila methodology (de Ávila et al., 2017). To evaluate CD86 expression, U937 cells were exposed to five different concentrations of H. speciosa latex $(200,100,50,25$, and $12.5 \mu \mathrm{g} / \mathrm{ml})$. After $45 \mathrm{~h}$ of incubation, cells were washed twice with $200 \mu \mathrm{L}$ of buffer (PBS $+5 \% \mathrm{FBS}, \mathrm{v} / \mathrm{v})$. They were then incubated with staining solution containing buffer $(95 \mu \mathrm{L})$ and FITC-conjugated anti-human CD86 monoclonal antibody $(5 \mu \mathrm{L})$ or FITC-isotype control IgG1 $(5 \mu \mathrm{L})$. After incubation cells were washed, $100 \mu \mathrm{L}$ of PI ( $3 \mu \mathrm{g} / \mathrm{mL})$ was added, and the mixture was analyzed in a flow cytometer (BDFACS Canto II, BD Biosciences, California) recording 10,000 events. Dead cells $\left(\mathrm{PI}^{+}\right)$were excluded from the CD86 expression analysis.

Data were calculated for each sample with a viability above or equal to $70 \%$. The percentage of $\operatorname{IgG}_{1}$ isotype positive cells was subtracted from the percentage of CD86 positive cells (Piroird et al., 2015). Results were expressed as stimulation index (SI), calculated as the isotype corrected percentage CD86 test/isotype corrected percentage CD86+ control $\times 100$, according to the following Equation 1:

$$
S I=\frac{\left(\% \mathrm{CD} 86 \text { treated }-\% \text { isotype } \mathrm{IgG}_{1} \text { treated }\right)}{\left(\% \mathrm{CD} 86 \text { control }-\% \text { isotype } \mathrm{IgG}_{1} \text { control }\right) \times 100}
$$

A positive response for skin sensitization was considered to be present when the SI was $\geq 150 \%$. The EC150, the concentration at which the tested material induced an SI of $150 \%$, was also obtained through linear regression.

\section{Results and Discussion}

We investigated the irritant and allergenic potential of the $H$. speciosa serum latex to verify if this biomaterial could be further safely used in a new non-allergenic formulation with potential healing for skin wound treatment. This is important once the number of sensitizing substances is increasing as new molecules are developed annually by the pharmaceutical industry (Cihák, 2009). Contact dermatitis is an inflammatory skin illness that can manifest as irritant or allergic, which present as symptoms pruritus, along with burning and stinging. These symptoms also are frequently associated with itch, pain, sleeplessness which have a negative impact on the life quality of their bearers (Owen et al., 2018). One of the recommended tests before commercial release of a product is the irritation test. Irritant contact dermatitis is a nonspecific skin response with release of inflammatory mediators (Litchman et al., 2017). Besides inflammation, it is discussed in the literature that dermal irritation begins with vascular changes. Thus, by using the HET-CAM assay it is possible to ascertain whether a substance may cause changes in the structure of the blood vessels present in the CAM and to assess whether the substance tested has potential for skin irritation (Reis Mansur et al., 2016). As result the application of $H$. speciosa serum latex to healthy CAMs produced hemorrhage and coagulation events at $30 \mathrm{~s}$ and 2 min over five-minute period, which classify this solution as slightly irritant (Figure 1 and Table 3).

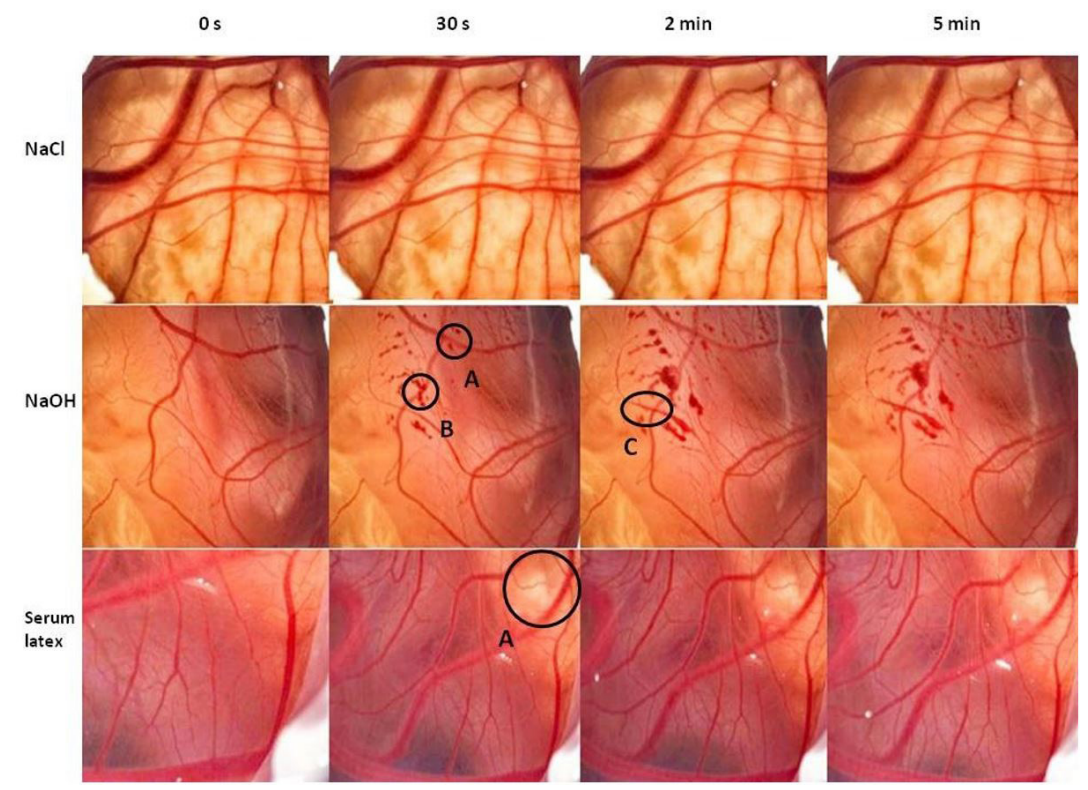

Figure 1. Photographs of CAM membrane after exposition to test solutions. The phenomena observed were coagulation, hemorrhage and hyperemia. The figure shows horizontally the different reaction time, and vertically the tested solutions. A. coagulation, B. hemorrhage and C. hyperemia. 
Table 3. Het-CAM assay experimental triplicate means values and classification of $H$. speciosa serum latex according to Luepke. SD: standard deviation.

\begin{tabular}{ccc}
\hline Test material & Mean \pm SD & Classification \\
\hline Negative control $(\mathrm{NaCl})$ & $0 \pm 0$ & Non-irritant \\
Positive control $(\mathrm{NaOH})$ & $15.5 \pm 3.44$ & Severely irritant \\
H. speciosa serum latex & $2.5 \pm 1.51$ & Slightly irritant \\
\hline
\end{tabular}

The cytotoxicity assays showed that all $H$. speciosa serum latex tested concentrations presented the viability greater than $70 \%$ and are in accordance with the required pattern of the OECD 442E (OECD, 2015). Then, the four highest concentrations $(200,100,50$, and $25 \mu \mathrm{g} / \mathrm{mL})$ of $H$. speciosa latex serum were chosen for analysis of sensitizing potential. After the evaluation of cell viability, the CD86 stimulation index (SI) was calculated using the U-SENS ${ }^{\mathrm{TM}}$ assay. The main advantage of this methodology is that it is an in vitro assay with superiority over animal models in identifying dermal sensitizers (Strickland et al., 2016). The sensitizer index obtained for the different concentrations of $H$. speciosa serum latex varied from IS = $60.2 \%$ in the smaller latex concentration to IS $=104.4 \%$ in the highest latex concentration. This result showed that the IS of $H$. speciosa serum in the highest concentration is smaller than the baseline for positive results of sensitization (IS $\geq 150 \%$ ). Then, our results suggested $H$. speciosa serum latex could be considered non-allergenic. Regarding allergies, it is known that one of the main responsible for latex sensitization are proteins. Thus, substances with a high protein content are more likely to cause an allergic response. For example, it is known that there are 15 allergenic proteins in the $\mathrm{H}$. brasiliensis latex, called $\mathrm{Hev}$ b1 to Hev b15. The knowledge about the protein content of an extract may indirectly suggest its allergenic potential. Thinking that, we quantified the total protein present in serum fraction of the $H$. speciosa and $H$. brasiliensis latex. Total protein content of $H$. speciosa serum latex obtained was $0.160 \pm 0.003 \mathrm{mg} / \mathrm{mL}$, which is almost 7 times smaller than the total protein found in $H$. brasiliensis serum latex $(1.06 \pm 0.02 \mathrm{mg} / \mathrm{mL})$. This could be an explanation about the non-allergenic potential of $H$. speciosa serum latex observed in this work. The discovery of non-allergenic biomaterials with proven biological activities are important sources for development of new medicines.

\section{Conclusions}

Ours results showed that $H$. speciosa serum latex is slightly irritant, no cytotoxic, no allergenic for human cells. Discovery of non-allergenic biomaterials with biological activities is important inputs for development of new medicine

\section{Acknowledgements}

We would like to thank the Brazilian funding agencies MCT/CNPq, FNDCT, CAPES, FINEP and FAPEG. LMA and SSC were supported by Universidade Estadual de Goiás by fellowships at the program PROBIP (Scientific Production Support Program); PJG and MCV were supported by CNPq productivity fellowships and AFC was supported by FAPEG student fellowship.

\section{References}

ALMEIDA, L.M., FLORIANO, J.F., RIBEIRO, T.P., MAGNO, L.N., DA MOTA, L.S.L.S., PEIXOTO, N., MRUÉ, F., MELO-REIS, P.R., LINO-JUNIOR, R.S., GRAEFF, C.F.O. and GONÇALVES, P.J., 2014. Hancornia speciosa latex for biomedical applications: physical and chemical properties, biocompatibility assessment and angiogenic activity. Journal of Materials Science. Materials in Medicine, vol. 25, no. 9, pp. 2153-2162. http://dx.doi.org/10.1007/s10856-014-5255-8. PMid:24973907.

ALMEIDA, L.M., MAGNO, L.N., PEREIRA, A.C., GUIDELLI, E.J., BAFFA FILHO, O., KINOSHITA, A. and GONÇALVES, P.J., 2019. Toxicity of silver nanoparticles released by Hancornia speciosa (Mangabeira) biomembrane. Spectrochimica acta. Part A, Molecular and Biomolecular Spectroscopy, vol. 210, pp. 329-334. http://dx.doi. org/10.1016/j.saa.2018.11.050. PMid:30472596.

ARAÚJO, M.M., MASSUDA, E.T. and HYPPOLITO, M.A., 2012. Anatomical and functional evaluation of tympanoplasty using a transitory natural latex biomembrane implant from the rubber tree Hevea brasiliensis. Acta Cirurgica Brasileira, vol. 27, no. 8, pp. 566-571. http://dx.doi.org/10.1590/S0102-86502012000800009. PMid:22850709.

ARRUDA, A.S., FARIA, R.Q., PEIXOTO, N., MOREIRA, A.S.F.P., FLORIANO, J.F., GRAEFF, C.F.O., GONÇALVES, P.J. and ALMEIDA, L.M., 2016. Mangabeira latex production evaluation in Cerrado region of Goiás. Ciência Florestal, vol. 26, no. 3, pp. 939-948. http://dx.doi. org/10.5902/1980509824222.

BIOCURE PHARMA BIOTECHNOLOGY, 2021 [viewed 27 March 2021]. Regedem $®$ e Biocure. Pele Nova Tecnologia S.A. [online]. Avaliable from: https://biocure.com.br/home/

BONETE, J.M., SILVA, G.D., GUIDELLI, E.J., GONÇALVES, P.J., ALMEIDA, L.M., BAFFA, O. and KINOSHITA, A., 2020. Tissue reaction and anti-biofilm action of new biomaterial composed of latex from Hancornia speciosa Gomes and silver nanoparticles. Anais da Academia Brasileira de Ciências, vol. 92, no. 4, pp. e20191584. http://dx.doi.org/10.1590/0001-3765202020191584. PMID: 33206788.

BRADFORD, M.M., 1976. A rapid and sensitive method for the quantitation of microgram quantities of protein utilizing the principle of protein-dye binding. Analytical Biochemistry, vol. 72, no. 1-2, pp. 248-254. http://dx.doi.org/10.1016/00032697(76)90527-3. PMid:942051.

CAVASSAN, N.R.V., CAMARGO, C.C., DE PONTES, L.G., BARRAVIERA, B., FERREIRA, R.S., MIOT, H.A., ABBADE, L.P.F. and DOS SANTOS, L.D. (2019). Correlation between chronic venous ulcer exudate proteins and clinical prole: A cross sectional study. Journal of Proteomics, vol. 192, pp. 280-290. http://dx.doi.org/10.1016/j. jprot.2018.09.009. PMid:30261322. 
CIHÁK, R., 2009. REACH - an overview. Interdisciplinary Toxicology, vol. 2, no. 2, pp. 42-44. http://dx.doi.org/10.2478/v10102-0090007-1. PMid:21217844.

D’ABADIA, P.L., BAILÃO, E.F.L.C., LINO-JÚNIOR, R.S., OLIVEIRA, M.G., SILVA, V.B., OLIVEIRA, L.A.R., CONCEIÇÃO, E., MELOREIS, P.R., BORGES, L.L., GONÇALVES, P.J. and ALMEIDA, L.M., 2020. Hancornia speciosa serum fraction latex stimulates the angiogenesis and extracellular matrix remodeling processes. Anais da Academia Brasileira de Ciências, vol. 92, no. 2, pp. e20190107. http://dx.doi.org/10.1590/0001-3765202020190107. PMid:32556049.

DE ÁVILA, R.I., DE SOUSA-VIEIRA, M., GAETI, M.P., MOREIRA, L.C., DE BRITO-RODRIGUES, L., DE OLIVEIRA, G.A., BATISTA, A.C., VINHAL, D.C., MENEGATTI, R. and VALADARES, M.C., 2017. Toxicity evaluation of the photoprotective compound LQFM048: eye irritation, skin toxicity and genotoxic endpoints. Toxicology, vol. 376, pp. 83-93. http://dx.doi.org/10.1016/j.tox.2016.04.007. PMid:27129947.

FLORIANO, J.F., DA MOTA, L.S.L.S., FURTADO, E.L., ROSSETTO, V.J. and GRAEFF, C.F., 2014. Biocompatibility studies of natural rubber latex from different tree clones and collection methods. Journal of Materials Science. Materials in Medicine, vol. 25, no. 2, pp. 461-470. http://dx.doi.org/10.1007/s10856-013-5089-9. PMid:24202915.

FLORIANO, J.F., NETO, F.C., DA MOTA, L.S.L.S., FURTADO, E.L., FERREIRA, R.S., BARRAVIERA, B., GONÇALVES, P.J., DE ALMEIDA, L.M., BORGES, F.A., HERCULANO, R.D. and DE OLIVEIRA GRAEFF, C.F., 2016. Comparative study of bone tissue accelerated regeneration by latex membranes from Hevea brasiliensis and Hancornia speciosa. Biomedical Physics \& Engineering Express, vol. 2, no. 4, pp. 4. http://dx.doi.org/10.1088/2057-1976/2/4/045007.

KELLY, K.J. and SUSSMAN, G., 2017. Latex allergy: where are we now and how did we get there? The Journal of Allergy and Clinical Immunology. In Practice, vol. 5, no. 5, pp. 1212-1216. http://dx.doi.org/10.1016/j.jaip.2017.05.029. PMid:28888250.

LITCHMAN, G., NAIR, P.A., ATWATER, A.R. and BEENISH,S.B., 2017 [viewed 27 March 2021]. Contact dermatitis [online]. Treasure Island (FL): Stat-Pearls Publishing. Avaliable from: ncbi.nlm. nih.gov/books/NBK459230/

LUEPKE, N.P., 1985. Hen's eggs chorioallantoic membrane test for irritation potential. Food and Chemical Toxicology, vol. 23, no. 2, pp. 287-291. http://dx.doi.org/10.1016/0278-6915(85)90030-4. PMid:4040077.

MARINHO, D.G., ALVIANO, D.S., MATHEUS, M.E., ALVIANO, C.S. and FERNANDES, P.D., 2011. The latex obtained from Hancornia speciosa Gomes possesses anti-inflammatory activity. Journal of Ethnopharmacology, vol. 135, no. 2, pp.530-537. http://dx.doi. org/10.1016/j.jep.2011.03.059. PMid:21463669.

MOURA, J.M., FERREIRA, J.F., MARQUES, L., HOLGADO, L., GRAEFF, C.F.O. and KINOSHITA, A., 2014. Comparison of the performance of natural latex membranes prepared with different procedures and PTFE membrane in guided bone regeneration (GBR) in rabbits. Journal of Materials Science. Materials in Medicine, vol. 25, no. 9, pp. 2111-2120. http://dx.doi.org/10.1007/s10856-0145241-1. PMid:24849612.

ORGANISATION FOR ECONOMIC COOPERATION AND DEVELOPMENT - OECD, 2015. Organization for Economic Cooperation and Development. Test Guideline 442E: in Vitro Skin Sensitization, human Cell Line Activation Test ( $h$-CLAT) . [online]. Paris: OECD Publishing. Avaliable from: http://www.oecd-ilibrary.org/ content/book/9789264229822-en

ORGANISATION FOR ECONOMIC COOPERATION AND DEVELOPMENT - OECD, 2016. Guideline for the testing of chemicals draft proposal for a new test guideline in vitro skin sensitisation: U937 cell line activation test (U-SENS ${ }^{T M}$ ) [online]. Paris: OECD Publishing. Avaliable from: https://www.oecd.org/env/ehs/testing/TGUsens-draft-TG_Dec15-2016-clean.pdf

OWEN, L., PENNINGTON, B., FISCHER, A. and JEONG, K., 2018. The cost-effectiveness of public health interventions examined by NICE from 2011 to 2016. Journal of Public Health (Oxford, England), vol. 40, no. 3, pp. 557-566. http://dx.doi.org/10.1093/ pubmed/fdx119. PMid:28977629.

PIROIRD, C., OVIGNE, J.M., ROUSSET, F., MARTINOZZI-TEISSIER, S., GOMES, C., COTOVIO, J. and ALÉPÉE, N., 2015. The myeloid U937 skin sensitization test (U-SENS) addresses the activation of dendritic cell event in the adverse outcome pathway for skin sensitization. Toxicology In Vitro, vol. 29, no. 5, pp. 901-916. http://dx.doi.org/10.1016/j.tiv.2015.03.009. PMid:25820135.

REIS MANSUR, M.C.P.P., LEITÃO, S.G., CERQUEIRA-COUTINHO, C., VERMELHO, A.B., SILVA, R.S., PRESGRAVE, O.A.F., LEITÃO, Á.A.C., LEITÃO, G.G., RICCI-JÚNIOR, E. and SANTOS, E.P., 2016. In vitro and in vivo evaluation of efficacy and safety of photoprotective formulations containing antioxidant extracts. Braz J Pharmacog, vol. 26, no. 2, pp. 251-258. http://dx.doi. org/10.1016/j.bjp.2015.11.006.

RIBEIRO, T.P., SOUSA, T.R., ARRUDA, A.S., PEIXOTO, N., GONÇALVES, P.J. and ALMEIDA, L.M., 2016. Evaluation of cytotoxicity and genotoxicity of Hancornia speciosa latex in Allium cepa root model. Brazilian Journal of Biology = Revista Brasileira de Biologia, vol. 76, no. 1, pp. 245-249. http://dx.doi.org/10.1590/15196984.20114. PMid:26909640.

SANTOS, V.L., OLIVEIRA, A.D., AMARAL, A.F., NISHI, E.T., JUNQUEIRA, J.B. and KIM, S.H., 2017. Quality of life in patients with chronic wounds: magnitude of changes and predictive factors. Revista da Escola de Enfermagem da USP, vol. 51, pp. e03250. http://dx.doi. org/10.1590/s1980-220x2016049603250. PMid:29019529.

STRICKLAND, J., ZANG, Q., KLEINSTREUER, N., PARIS, M., LEHMANN, D.M., CHOKSI, N., MATHESON, J., JACOBS, A., LOWIT, A., ALLEN, D. and CASEY, W., 2016. Integrated decision strategies for skin sensitization hazard. Journal of Applied Toxicology, vol. 36, no. 9, pp. 1150-1162. http://dx.doi.org/10.1002/jat.3281. PMid:26851134. 